\title{
Nerolidol, an Antiulcer Constituent from the Essential Oil of Baccharis dracunculifolia DC (Asteraceae)
}

\author{
Fernando Canani Klopell ${ }^{\mathrm{a}}$, Marivane Lemos ${ }^{\mathrm{a}}$, João Paulo Barreto Sousa ${ }^{\mathrm{b}}$, \\ Eros Comunello ${ }^{\mathrm{c}}$, Edson Luis Maistro ${ }^{\mathrm{d}}$, Jairo Kennup Bastos ${ }^{\mathrm{b}}$, \\ and Sérgio Faloni de Andrade ${ }^{\mathrm{a}, \mathrm{e}, *}$
}

a Núcleo de Ciência e Tecnologia, Área de Ciências Biológicas e da Saúde, Universidade do Oeste de Santa Catarina, Campus de Videira, Rua Paese, 198, Bairro Universitário, Videira, SC, CEP 89560-900, Brazil. Fax: +4935511444. E-mail: sfaloni@bol.com.br

b Faculdade de Ciências Farmacêuticas de Ribeirão Preto, Universidade de São Paulo, Ribeirão Preto, SP, Brazil

c Programa de Mestrado em Computação Aplicada, Universidade do Vale do Itajaí UNIVALI, São José, Santa Catarina, Brazil

d Faculdade de Filosofia e Ciências, Universidade Estadual Paulista - UNESP, Marília, SP, Brazil

e Programa de Mestrado em Ciências Farmacêuticas, Núcleo de Investigações QuímicoFarmacêuticas (NIQFAR), Universidade do Vale do Itajaí - UNIVALI, Itajaí,

Santa Catarina, Brazil

* Author for correspondence and reprint requests

Z. Naturforsch. 62 c, 537-542 (2007); received January 12/March 2, 2007

In this study, the antiulcerogenic effect of essential oil from Baccharis dracunculifolia was evaluated using the model of acute gastric lesions induced by ethanol. The ulcerative lesion index (ULI) was significantly reduced by oral administration of the essential oil of B. dracunculifolia at doses of 50,250 and $500 \mathrm{mg} / \mathrm{kg}$ which reduced the lesions by $42.79,45.70$ and $61.61 \%$, respectively. The analysis of the chemical composition of the essential oil from $B$. dracunculifolia by GC showed that this was composed mainly of mono- and sesquiterpenes and the majority compound was nerolidol. Therefore, antiulcerogenic activity of nerolidol $(50,250$ and $500 \mathrm{mg} / \mathrm{kg})$ was investigated using ethanol-, indomethacin- and stress-induced ulcer models in rat. In the stress-induced ulcer model, a significant reduction of the ULI in animals treated with nerolidol $(50,250$ and $500 \mathrm{mg} / \mathrm{kg})$ and cimetidine $(100 \mathrm{mg} / \mathrm{kg})$ was observed, compared to the control group $(p<0.05)$. The percentage of inhibition of ulcer was $41.22,51.31,56.57$ and $53.50 \%$ in groups treated with $50,250,500 \mathrm{mg} / \mathrm{kg}$ of nerolidol and $100 \mathrm{mg} / \mathrm{kg}$ of cimetidine (positive control), respectively. Regarding ethanol- and indomethacin-induced ulcer models, it was observed that the treatment with nerolidol (250 and $500 \mathrm{mg}$ / $\mathrm{kg})$ significantly reduced the ULI in comparison with the control group $(p<0.05)$. The dose of $50 \mathrm{mg} / \mathrm{kg}$ reduced the parameters analyzed but this was not statistically significant. In the ethanol-induced model percentage of inhibition of ulcer was $34.20,52.63,87.63$ and $50.87 \%$ in groups treated with $50,250,500 \mathrm{mg} / \mathrm{kg}$ of nerolidol and $30 \mathrm{mg} / \mathrm{kg}$ of omeprazol (positive control), respectively. In indomethacin-ulcer the percentage of inhibition of ulcer was 34.69, $40.80,51.02$ and $46.93 \%$ in groups treated with $50,250,500 \mathrm{mg} / \mathrm{kg}$ of nerolidol and $100 \mathrm{mg} /$ $\mathrm{kg}$ of cimetidine (positive control), respectively. The results of this study show that nerolidol displays antiulcer activity, as it significantly inhibited the formation of ulcers induced in different animal models. However, further pharmacological and toxicological investigations, to delineate the mechanism(s) of action and the toxic effects, are required to allow the use of nerolidol for the treatment of gastric ulcer.

Key words: Baccharis dracunculifolia, Antiulcerogenic, Essential Oil, Nerolidol

\section{Introduction}

Gastric and duodenal ulcers are illnesses that affect a considerable number of people in the world and they are induced by several factors, such as: stress, smoking, nutritional deficiencies and ingestion of nonsteroidal anti-inflammatory drugs (Nash et al., 1994). The current medicinal treat- ment of peptic ulcer is generally based on the inhibition of gastric acid secretion by histamine H2antagonists, proton pump inhibitors, antimuscarinics, as well as on the acid-independent therapy provided by sucralfate and bismuth cholinergics (Bighetti et al., 2005). However, the majority of these drugs produce several adverse reactions, such as: hypersensitivity, arrhythmia, impotence, 
gynecomastia and hematopoietic changes (Chan and Leung, 2002). Thus, the development of more effective and less toxic antiulcer agents is necessary.

An extensive variety of chemical compounds isolated from medicinal plants display anitulcer activity (Borrelli and Izzo, 2000), and several plants are used in the folk medicine for their antiulcer properties.

The Baccharis genus representes more than 500 species distributed mainly in the tropical areas of South America. Many of them are extensively used in folk medicine for the treatment or prevention of anemias, inflammations, diabetes, stomach, liver and prostate diseases (Verdi et al., 2005).

Baccharis dracunculifolia DC (Asteraceae), a native plant from Brazil commonly known as "Alecrim-do-campo" and "Vassoura", is the most important botanical source of Southeastern Brazilian propolis, known as green propolis for its color (Park et al., 2002; Marcucci et al., 1998). It is also important to take into consideration that $B$. dracunculifolia produces an essential oil composed of a mixture of aliphatic and cyclic volatile terpene hydrocarbons and their corresponding oxygenated isoprenoid derivates and analogues, which can be obtained from the plant by steam distillation (Magiatis et al., 2002). In this regard, some essential oils have been reported to display antiulcer properties (Esteves et al., 2005; Hiruma-Lima et al., 2002).

Besides, it was observed that one of the main compounds of the essential oil from $B$. dracunculifolia is nerolidol. This substance is a sesquiterpene found in many essential oils (Koudou et al., 2005). It has been previously shown that nerolidol has antimalarial (Lopes et al., 1999) and antileishmanial activity (Arruda et al., 2005). Moreover, Koudou et al. (2005) described that essential oil from Canarium schweinfurthii, which possesses nerolidol as one of the main components, presented antinociceptive activity.

Since, no studies on the antiulcer activity of this substance were carried out, the present study was undertaken to evaluate the antiulcerogenic property of nerolidol using different animal models.

\section{Materials and Methods}

\section{Plant material}

The aerial parts of Baccharis dracunculifolia were collected in Franca, São Paulo state, Brazil, in February 2005. The plant material was authenticated by Nelson Ivo Matzenbacher, and a voucher specimen was deposited in the herbarium of the Centro Pluridisciplinar de Pesquisas Químicas, Biológicas e Agronômicas (CPQBA) of Universidade Estadual de Campinas, Campinas, São Paulo state, Brazil.

\section{Drugs, reagents and solvents}

Indomethacin, cimetidine, omeprazol and nerolidol were purchased from Sigma Aldrich (St. Louis, MD, USA). All other used reagents and solvents were of analytical grade.

\section{Essential oil obtainment}

The essential oil of the dry leaves $(200 \mathrm{~g})$ was extracted by hydro-distillation using a Clevengertype apparatus. After extraction, the volume of essential oil obtained was measured and the essential oil conditioned in hermetically sealed glass containers with rubber lids, covered with aluminum foil to protect the contents from light and kept under refrigeration at $8^{\circ} \mathrm{C}$ until used.

\section{Gas chromatography (GC)}

The GC analysis of the essential oil was carried out in a Hewelett Packard GC apparatus, model $6890 \mathrm{~N}$, equipped with a split/splitless injector inlet and a flame ionization detector (FID). The output was recorded using a workstation. An HP-5 capillary column $(30 \mathrm{~m}$ of length $\times 0.32 \mathrm{~mm}$ of internal diameter $\times 0.25 \mathrm{~mm}$ of film thickness) was used. Hydrogen at the flow rate of $2.0 \mathrm{~mL} / \mathrm{min}$ was employed as the carrier gas and the GC oven temperature was programmed from 55 to $120^{\circ} \mathrm{C}$ at $20^{\circ} \mathrm{C} /$ min, from 120 to $150{ }^{\circ} \mathrm{C}$ at $1.5^{\circ} \mathrm{C} / \mathrm{min}, 150$ to $180^{\circ} \mathrm{C}$ at $20^{\circ} \mathrm{C} / \mathrm{min}$ and held at $180{ }^{\circ} \mathrm{C}$ for $5 \mathrm{~min}$. The temperatures of the injector and detector ports were kept at $210{ }^{\circ} \mathrm{C}$ and $250{ }^{\circ} \mathrm{C}$, respectively. The injector was operated in a split mode of $1 / 3$.

\section{Gas chromatography/mass spectrometry (GC/MS)}

The GC/MS analysis of the essential oil was performed using a Hewlett-Packard 5890 gas chromatography equipped with a Zebron ZB-5 column $(30 \mathrm{~m} \times 0.25 \mathrm{~mm} \times 0.25 \mu \mathrm{m})$ and a mass spectrometer 5971 of the same company which was operated in EI mode. Hydrogen at the flow rate of $1.0 \mathrm{~mL} / \mathrm{min}$ was employed as the carrier gas and the increasing temperature gradient was: $55^{\circ} \mathrm{C}$ 
$(0 \mathrm{~min}) ; 20^{\circ} \mathrm{C} / \mathrm{min}$ to $120^{\circ} \mathrm{C} ; 120^{\circ} \mathrm{C} \quad(0 \mathrm{~min})$; $1.5^{\circ} \mathrm{C} / \mathrm{min}$ to $150{ }^{\circ} \mathrm{C} ; 150^{\circ} \mathrm{C}(0 \mathrm{~min}) ; 20^{\circ} \mathrm{C} / \mathrm{min}$ to $180^{\circ} \mathrm{C}(5 \mathrm{~min})$. The temperatures of the injector and detector ports were kept at $210^{\circ} \mathrm{C}$ and $250{ }^{\circ} \mathrm{C}$, respectively. The injector was operated in a split mode of $1 / 3$.

Identification of the components was achieved from their linear retention indices on HP-5 and Zebron ZB-5 columns, determined with references to a homologous series of $\mathrm{C}_{9}-\mathrm{C}_{20} n$-alkanes, and by comparison of their mass spectral fragmentation patterns with those stored in the data bank (Wiley/NBS library) and the literature (Adams, 1995; Ferracini et al., 1995; Queiroga et al., 1990).

\section{Animals}

Male Wistar rats, weighing 200-250 g, were provided by Central Animal House of the West University of Santa Catarina (UNOESC), Campus of Videira. The animals were housed in groups of five in standard cages at room temperature $\left[(25 \pm 3){ }^{\circ} \mathrm{C}\right]$ in $12 \mathrm{~h}$ dark/12 $\mathrm{h}$ light cycles, with both food and water ad libitum. $12 \mathrm{~h}$ before the experiments they were transferred to the laboratory and maintained only with water ad libitum. Animals used in the present study were housed and cared in accordance with the Federal Government Legislation on Animal Care. Also, the experiments were authorized by the Ethical Committee for Animal Care of the University of the West of Santa Catarina, Brazil.

\section{Evaluation of antiulcer activity of the essential oil in the ethanol-induced ulcer model}

The experiment was performed according to the method of Morimoto et al. (1991). After $12 \mathrm{~h}$ of fasting, rats were randomly divided into five groups of six animals each. To the first group it was given $1 \mathrm{~mL}$ of vehicle ( $1 \%$ Tween- 80 aqueous solution), and the second group was treated with omeprazol $(30 \mathrm{mg} / \mathrm{kg})$. The remaining three groups received 50,250 and $500 \mathrm{mg} / \mathrm{kg}$ of esential oil, respectively. All treatments were administered orally. $1 \mathrm{~h}$ after treatment, all rats received $1 \mathrm{~mL}$ of $99.5 \%$ ethanol to induce gastric ulcer. $1 \mathrm{~h}$ latter the animals were sacrificed by cervical dislocation, the stomachs were removed and opened along the greater curvature. Stomachs were gently rinsed with water to remove gastric contents and blood clots to be later scanned. The obtained images were analyzed by the specific software "EARP" (developed by Dr. Eros Comunello, Universidade do Vale do Itajaí, São José, SC, Brazil) for measuring each lesion point. The ulcers were classified as level I, ulcer area $<1 \mathrm{~mm}^{2}$; level II, ulcer area $1-$ $3 \mathrm{~mm}^{2}$; and level III, ulcer area $>3 \mathrm{~mm}^{2}$. The following parameters were determined: (i) ulcerative lesion index (ULI) as $1 \times$ (number of ulcers of level I) $+2 \times($ number of ulcers of level II $)+3 \times($ number of ulcers of level III); (ii) curative ratio $(\% \mathrm{C})$, which was determined as follows: $\% \mathrm{C}=100-$ $\left(\mathrm{IU}_{\text {treated }} \times 100 / \mathrm{IU}_{\text {control }}\right)$, where IU is the index of ulcer; (iii) total area of lesion; (iv) percentage of lesion area in relation to the total stomach area.

\section{Evaluation of antiulcer activity of nerolidol in different ulcer models}

Ethanol-induced ulcer model

The experiment was undertaken as described above. Five animal groups of six animals each were treated orally with $1 \mathrm{~mL}$ of vehicle $(1 \%$ Tween-80 aqueous solution), omeprazol $(30 \mathrm{mg} /$ $\mathrm{kg}$ ) or 50,250 and $500 \mathrm{mg} / \mathrm{kg}$ of nerolidol, respectively. $1 \mathrm{~h}$ after treatment, all rats received $1 \mathrm{~mL}$ of $99.5 \%$ ethanol to induce gastric ulcer. $1 \mathrm{~h}$ latter the animals were sacrificed by cervical dislocation, the stomachs were removed and opened along the greater curvature. Stomachs were gently rinsed with water to remove gastric contents and blood clots to be later scanned. The obtained images were analyzed using the parameters previously described.

Nonsteroidal anti-inflammatory drug (NSAID)induced ulcer

The experiment was performed according to the method of Nwafor et al. (2000) with a few modifications. After $12 \mathrm{~h}$ of fasting, rats were randomly divided into five groups of six animals each. To the first group it was given $1 \mathrm{~mL}$ of vehicle (1\% Tween- 80 aqueous solution), and the second group was treated with cimetidine $(100 \mathrm{mg} / \mathrm{kg})$. The remaining three groups received 50,250 and $500 \mathrm{mg} /$ $\mathrm{kg}$ of nerolidol, respectively. All treatments were administered orally. $1 \mathrm{~h}$ after treatment, all rats received indomethacin $(100 \mathrm{mg} / \mathrm{kg})$ to induce gastric ulcer. $4 \mathrm{~h}$ after treatment with indomethacin animals were sacrificed by cervical dislocation, the stomachs were removed and opened along the greater curvature. Stomachs were gently rinsed with water to remove gastric contents and blood clots to be later scanned. The obtained images 
were analyzed using the parameters previously described.

Stress-induced ulcer

The method described by Basile et al. (1990) was employed in this assay. Groups of six animals were treated as previously described, and $30 \mathrm{~min}$ later, each animal was placed in a tube and immersed vertically until the water reached the neck region in a tank with current water at $25^{\circ} \mathrm{C}$ for $17 \mathrm{~h}$. After this period, the rats were sacrificed by cervical dislocation. The stomachs were removed, opened along the greater curvature, followed by gently washing with water to remove gastric contents and blood clots to be later scanned. The obtained images were analyzed using the parameters described previously.

\section{Statistical analysis}

Data are reported as means \pm standard error of the mean (S.E.M.) and were compared using oneway analysis of variance (ANOVA), followed by Dunnet's pairwise test. $p$ Values $<0.05$ were considered significant.

\section{Results and Discussion}

The oil yield was $0.6 \%$ based on the dry weight of the plant. The analysis of essential oil of $B$. dracunculifolia used in this study by GC showed that this was composed mainly of mono- and sesquiterpenes and the majority compound was nerolidol, which represented $23.6 \%$.

The ulcerative lesion index (ULI) was significantly reduced by oral administration of the essential oil of B. dracunculifolia at the doses of 50, 250 and $500 \mathrm{mg} / \mathrm{kg}$ which reduced the lesions by 42.79 , 45.70 and $61.61 \%$, respectively. In the group treated with omeprazol $(30 \mathrm{mg} / \mathrm{kg})$ reduction in the ULI of $72.44 \%$ was observed. Besides, total area of lesion and percentage of lesion area also were diminished at all doses of essential oil used, when compared with the control group (Table I).

The effects of nerolidol on the three types of gastric lesion models used are displayed in Table II.

In the stress-induced ulcer model, it was observed a significant reduction in lesion index, total lesion area and in percentage of lesion in animals treated with nerolidol $(50,250$ and $500 \mathrm{mg} / \mathrm{kg}$ ) and cimetidine $(100 \mathrm{mg} / \mathrm{kg})$, compared to the control group $(p<0.05)$. The percentage of inhibition of ulcer was $41.22,51.31,56.57$ and $53.50 \%$ in groups treated with $50,250,500 \mathrm{mg} / \mathrm{kg}$ of nerolidol and $100 \mathrm{mg} / \mathrm{kg}$ of cimetidine (positive control), respectively.

Regarding the ethanol-induced ulcer model, it was observed that the treatment with nerolidol $(250$ and $500 \mathrm{mg} / \mathrm{kg}$ ) and omeprazol $(30 \mathrm{mg} / \mathrm{kg}$ ) significantly reduced the lesion index, the total lesion area and the percentage of lesion, in comparison with the control group $(p<0.05)$. The dose of $50 \mathrm{mg} / \mathrm{kg}$ reduced the parameters analyzed but was not statistically significant. The percentage of inhibition of ulcer was $34.20,52.63,87.63$ and $50.87 \%$ in groups treated with $50,250,500 \mathrm{mg} / \mathrm{kg}$ of nerolidol and $30 \mathrm{mg} / \mathrm{kg}$ of omeprazol (positive control), respectively.

The treatment with nerolidol (250 and $500 \mathrm{mg} /$ $\mathrm{kg})$ and cimetidine $(100 \mathrm{mg} / \mathrm{kg})$ reduced significantly all the evaluated parameters in comparison with the control group $(p<0.05)$ in the indomethacin-induced ulcer model. As well as observed in the assay of ethanol-induced ulcer the dose of $50 \mathrm{mg} / \mathrm{kg}$ reduced the parameters analyzed but was not statistically significant. In this model, the percentage of inhibition of ulcer was $34.69,40.80$,

Table I. Effects of different doses of essential oil (EO) of Baccharis dracunculifolia on ethanol-induced gastric lesions in rats.

\begin{tabular}{lccccc}
\hline Treatment (p.o.) & $\begin{array}{c}\text { Dose } \\
{[\mathrm{mg} / \mathrm{kg}]}\end{array}$ & $\begin{array}{c}\text { Total area of } \\
\text { lesion }\left[\mathrm{mm}^{2}\right]\end{array}$ & $\begin{array}{c}\text { \% of lesion } \\
\text { area }\end{array}$ & $\begin{array}{c}\text { Ulcer lesion } \\
\text { index }\end{array}$ & $\begin{array}{c}\text { Curative ratio } \\
(\%)\end{array}$ \\
\hline Control & - & 229.55 & 27.0 & $113.02 \pm 13.42$ & - \\
Omeprazol & 30 & $48.00^{*}$ & $2.74^{*}$ & $31.14 \pm 2.22^{*}$ & 72.44 \\
EO & 50 & $35.73^{*}$ & $4.33^{*}$ & $64.65 \pm 3.70^{*}$ & 42.79 \\
& 250 & $12.85^{*}$ & $1.81^{*}$ & $61.35 \pm 6.83^{*}$ & 45.70 \\
\end{tabular}

Results are means \pm S.E.M. for six rats. Statistical comparison was performed using ANOVA followed by Dunnet's test.

$* p<0.05$ when compared to the control group. 
Table II. Effects of nerolidol and omeprazol or cimetidine on ethanol-, indomethacin- and stress-induced gastric ulcers in rats.

\begin{tabular}{|c|c|c|c|c|c|c|}
\hline Method & Treatment (p.o.) & $\begin{array}{c}\text { Dose } \\
{[\mathrm{mg} / \mathrm{kg}]}\end{array}$ & $\begin{array}{l}\text { Total area of } \\
\text { lesion }\left[\mathrm{mm}^{2}\right]\end{array}$ & $\begin{array}{c}\% \text { of lesion } \\
\text { area }\end{array}$ & $\begin{array}{l}\text { Ulcer lesion } \\
\text { index }\end{array}$ & $\begin{array}{c}\text { Curative ratio } \\
(\%)\end{array}$ \\
\hline Ethanol & $\begin{array}{l}\text { Control } \\
\text { Omeprazol } \\
\text { Nerolidol }\end{array}$ & $\begin{array}{r}- \\
30 \\
50 \\
250 \\
500\end{array}$ & $\begin{array}{c}53.26 \pm 11.78 \\
11.40 \pm 2.23^{*} \\
30.08 \pm 12.67 \\
8.76 \pm 1.99^{*} \\
1.41 \pm 0.91 *\end{array}$ & $\begin{array}{l}7.70 \pm 2.54 \\
1.21 \pm 0.22 * \\
3.29 \pm 1.26 \\
1.32 \pm 0.31 * \\
0.24 \pm 0.15^{*}\end{array}$ & $\begin{array}{r}22.80 \pm 3.39 \\
11.20 \pm 0.96^{*} \\
15.00 \pm 4.69 \\
10.80 \pm 1.91^{*} \\
2.82 \pm 1.59^{*}\end{array}$ & $\begin{array}{c}- \\
50.87 \\
34.20 \\
52.63 \\
87.63\end{array}$ \\
\hline Indomethacin & $\begin{array}{l}\text { Control } \\
\text { Cimetidine } \\
\text { Nerolidol }\end{array}$ & $\begin{array}{r}- \\
100 \\
50 \\
250 \\
500\end{array}$ & $\begin{array}{rll}17.19 \pm & 3.93 \\
6.17 \pm & 0.97 * \\
7.18 \pm & 3.64 \\
6.50 \pm & 1.92^{*} \\
4.66 \pm & 1.00^{*}\end{array}$ & $\begin{array}{l}3.12 \pm 0.62 \\
1.11 \pm 0.18 * \\
1.11 \pm 0.63 \\
1.07 \pm 0.28 * \\
0.97 \pm 0.26^{*}\end{array}$ & $\begin{array}{r}19.60 \pm 1.28 \\
10.40 \pm 2.58^{*} \\
12.80 \pm 1.39 \\
11.60 \pm 1.96^{*} \\
9.60 \pm 1.36^{*}\end{array}$ & $\begin{array}{c}- \\
46.93 \\
34.69 \\
40.80 \\
51.02\end{array}$ \\
\hline Stress & $\begin{array}{l}\text { Control } \\
\text { Cimetidine } \\
\text { Nerolidol }\end{array}$ & $\begin{array}{r}- \\
100 \\
50 \\
250 \\
500\end{array}$ & $\begin{array}{r}56.75 \pm 10.23 \\
12.73 \pm 1.67 * \\
10.48 \pm 1.95^{*} \\
9.92 \pm 3.22^{*} \\
9.97 \pm 2.93^{*}\end{array}$ & $\begin{array}{l}6.98 \pm 1.04 \\
2.23 \pm 0.45^{*} \\
1.46 \pm 0.32^{*} \\
1.45 \pm 0.45^{*} \\
1.24 \pm 0.37 *\end{array}$ & $\begin{array}{l}45.60 \pm 7.63 \\
21.20 \pm 3.05^{*} \\
26.80 \pm 3.52^{*} \\
22.20 \pm 5.09^{*} \\
19.80 \pm 2.57^{*}\end{array}$ & $\begin{array}{c}- \\
53.50 \\
41.22 \\
51.31 \\
56.57\end{array}$ \\
\hline
\end{tabular}

Results are means \pm S.E.M. for six rats. Statistical comparison was performed using ANOVA followed by Dunnet's test.

$* p<0.05$ when compared to the control group.

51.02 and $46.93 \%$ in groups treated with 50, 250, $500 \mathrm{mg} / \mathrm{kg}$ of nerolidol and $100 \mathrm{mg} / \mathrm{kg}$ of cimetidine (positive control), respectively.

The present study showed that nerolidol (Fig. 1) possesses gastroprotective activity as evidenced by its significant inhibition in the formation of ulcers induced by physical and chemical agents. The protocols undertaken in this study are the most commonly used in the evaluation of antiulcer agents in rats. Moreover, results indicate that nerolidol produced a dose-dependent gastroprotection in all models of ulcerinduction undertaken in this work.

Nerolidol was selected for this work based on the fact that this compound is one of the main

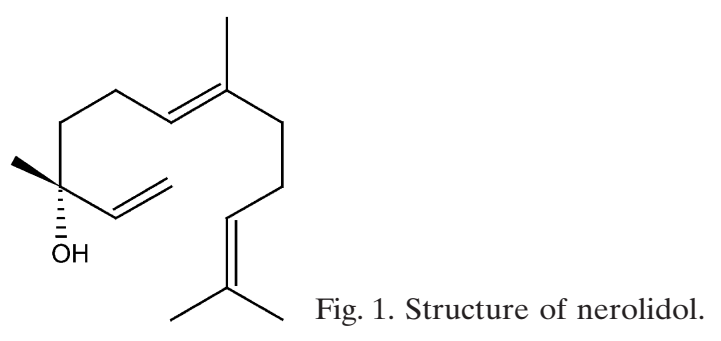

components of the essencial oil from B. dracunculifolia. Besides, B. dracunculifolia is the most important botanical source of Southeastern Brazilian propolis, known as green propolis for its color (Marcucci et al., 1998; Park et al., 2002). Previous works have described the antiulcer activity of green propolis (Barros et al., 2007) and B. dracunculifolia hydroalcoholic extract (Lemos et al., 2007).

In conclusion, the results of this study show that nerolidol displays antiulcer activity. However, further pharmacological and toxicological investigations, to delineate the mechanism(s) of action and the toxic effects, are required to allow the use of nerolidol for the treatment of gastric ulcer.

\section{Acknowledgements}

The authors are grateful to FAPESP (Process 04/13005-1) for financial support. We are also thankful to P. M. Magalhães, C. L. Queiroga (Centro de Pesquisas Químicas, Biológicas e Agrícolas CPQBA-UNICAMP) and to N. I. Matzenbacher. 
Adams R. P. (1995), Identification of Essential Oil Components by Gas Chromatography/Mass Spectroscopy. Allures Publishing Co., Carol Stream, Illinois.

Arruda D. C., D'Alexandri F. L., Katzin A. M., and Uliana S. R. B. (2005), Antileishmanial activity of the terpene nerolidol. Antimicrob. Agents Chemother. 49, 1679-1687.

Barros M. P., Sousa J. P. B., Bastos J. K., and Andrade S. F. (2007), Effect of Brazilian green propolis on experimental gastric ulcers in rats. J. Ethnopharmacol. 110, $567-571$.

Basile A. C., Sertié J. A. A., Panizza S., Oshiro T. T., and Azzolini C. A. (1990), Pharmacological assay of Casearia silvestris. I: Preventive anti-ulcer activity and toxicity of the leaf crude extract. J. Ethnopharmacol. 30, 185-197.

Bighetti A. E., Antônio M. A., Kohn L. K., Rehder V. L. G., Foglio M. A., Possenti A., Vilela L., and Carvalho J. E. (2005), Antiulcerogenic activity of a crude hydroalcoholic extract and coumarin isolated from Mikania laevigata Schultz Bip. Phytomedicine 12, $72-77$.

Borrelli F. and Izzo A. A. (2000), The plant kingdom as a source of anti-ulcer remedies. Phytother. Res. 14, $581-591$.

Chan F. K. and Leung W. K. (2002), Peptic ulcer disease. Lancet 360, 933-941.

Esteves I., Souza I. R., Rodrigues M., Cardoso L. G. V., Santos L. S., Sertie J. A. A., Perazzo F. F., Lima L. M., Schneedorf J. M., Bastos J. K., and Carvalho J. C. T. (2005), Gastric antiulcer and anti-inflammatory activities of the essential oil from Casearia sylvestris Sw. J. Ethnopharmacol. 101, 191-196.

Ferracini V. L., Paraíba L. C., Leitão Filho H. F., Da Silva A. G., Nascimento L. R., and Marsaioli A. J. (1995), Essencial oils of seven Brazilian Baccharis species. J. Essent. Oil Res. 7, 355-367.

Hiruma-Lima C. A., Gracioso J. S., Bighetti E. J. B., Grassi-Kassisse D. M., Nunes D. S., and Brito A. R. M. S. (2002), Effect of essential oil obtained from Croton cajucara Benth. on gastric ulcer healing and protective factors of the gastric mucosa. Phytomedicine 9, 523-529.

Koudou J., Abena A. A., Ngaissona P., and Bessiére J. M. (2005), Chemical composition and pharmacolog- ical activity of essential oil of Canarium schweinfurthii. Fitoterapia 76, 700-703.

Lemos M., Barros M. P., Sousa J. P. B., Silva-Filho A. A., Bastos J. K., and Andrade S. F. (2007), Baccharis dracunculifolia, the main botanical source of Brazilian green propolis, displays antiulcer activity. J. Pharm. Pharmacol. 59, 603-608.

Lopes N. P., Massuo M. J., Andrade E. H. A., Maia J. G. S., Yoshida M., Planchart A. R., and Katzin A. M. (1999), Antimalarial use of volatile oil from leaves of Virola surinamensis (Rol.) Warb. by Waiãpi Amazon Indians. J. Ethnopharmacol. 67, 313-319.

Magiatis P., Skaltsounis A. L., Chinou I., and Haroutounian S. A. (2002), Chemical composition and in-vitro antimicrobial activity of the essential oils of three Greek Achillea species. Z. Naturforsch. 57c, 287-290.

Marcucci M. C., Rodriguez J., Ferreres F., Bankova V., Groto R., and Popov S. (1998), Chemical composition of Brazilian propolis from São Paulo state. Z. Naturforsch. 53c, $117-119$.

Morimoto Y., Shimohara K., Oshima S., and Sukamoto T. (1991), Effects of the new anti-ulcer agent KB-5492 on experimental gastric mucosal lesions and gastric mucosal defensive factors, as compared to those of terprenone and cimetidine. Jpn. J. Pharmacol. 57, $595-605$.

Nash J., Lambert L., and Deakin M. (1994), Histamine H2-receptor. Antagonist in peptic ulcer disease. Evidence for a prophylactic use. Drugs 47, 862-871.

Nwafor P. A., Okwuasaba F. K., and Binda L. G. (2000), Antidiarrhoeal and antiulcerogenic effects of methanolic extract of Asparagus pubescens root in rats. J. Ethnopharmacol. 72, 421-427.

Park Y. K., Alencar S. M., and Aguiar C. L. (2002), Botanical origin and chemical composition of Brazilian propolis. J. Agric. Food Chem. 50, 2502-2506.

Queiroga C. L., Fukai A., and Marsioli A. J. (1990), Composition of the essential oil of Vassoura. J. Braz. Chem. Soc. 1, 105-109.

Verdi L. G., Brighente I. M. C., and Pizzolatti M. G. (2005), Gênero Baccharis (Asteraceae): Aspectos Químicos, Econômicos e Biológicos. Quím. Nova 28, 85-94. 